\title{
THE STRUCTURE OF THE DEFERRED INCOME TAX AND ITS INFLUENCE ON INDICATORS DESCRIBING THE ECONOMIC PERFORMANCE OF COMMERCIAL INSURANCE COMPANIES
}

\author{
H. Bohušová, E. Vávrová
}

Received: December 15, 2006

\begin{abstract}
BOHUŠOVÁ, H., VÁVROVÁ, E.: The structure of the deferred income tax and its influence on indicators describing the economic performance of commercial insurance companies. Acta univ. agric. et silvic. Mendel. Brun., 2007, LV, No. 3, pp. 143-156

The main objective of this paper is presentation of findings gathered through an analysis of items that cause deferred income tax in commercial insurance companies in the Czech insurance market. The evaluation of the subject is focused in accordance with the concept of the presented paper as regards structure analysis of the deferred tax, working with a selection of insurers - members of the Czech Insurance Association. We study, document and evaluate the influence of the deferred income tax being related with the given available income, as well as related to the effective income tax rate in a commercial insurance company. This analysis concerns the evaluation of the present-day degree of transformation and approximation of the Czech system of insurance in the process of harmonization with the European insurance system.
\end{abstract}

accounting, deferred income tax, commercial insurance company, assets, liabilities, indicator, life insurance, non-life insurance

A commercial insurance company (further insurance company) acting as a business entity has - compared to other business entities - a number of specifics, and its system of accounting has to be able to reflect them. Insurance companies provide insurance, reinsurance, and perform activities connected with insurance and reinsurance. In this paper, the term "insurance company" refers to any insurance company established according to the - currently in force - Act No. 363/1999 Coll., on insurance, as amended by subsequent regulations (above all, Act No. 39/2004 Coll.). An insurance company is a special financial institution. It is required to create and manage technical provisions to cover its future liabilities. Provisions have to be created regardless of the premium rate.
Act No. 563/1991 Coll., on accounting, as well as other accounting-related regulations require all commercial insurance companies to keep records on the deferred income tax. The current procedure to calculate and record the deferred income tax is regulated by Decree No. 502/2002 Coll., implementing certain regulations of the Accounting Act for accounting entities that are insurance companies. The procedure is also regulated by the Czech Accounting Standards for accounting entities that keep their records in accordance with Decree No. 502/2002 Coll. (the Czech Accounting Standards for Insurance Companies), and is compatible with methodological procedures regulated by international accounting standards, in particular, by IAS 12 - Income Taxes. The significance 
of recording the deferred income tax lies especially in the ability to show the available income in the insurance company's financial statement in a form that tallies with economic reality and that does not depend solely on tax-related legislation.

The focus of this paper is two-fold. In the first part we deal with methodological aspects in relation with a general definition of the accounting category "deferred tax", its importance for insurance companies' accounting, with stress on an analysis of individual items that cause deferred tax in commercial insurance companies. We also deal with the methodological procedure of calculating and recording this tax in accounting books. In the second part of the paper we present an analysis of the deferred tax structure in a selection of commercial insurance companies, and an evaluation of how recording the tax influences the effective income tax rate and the available income in insurance companies.

\section{DEFINITION OF THE PROBLEM AND METHODOLOGY}

In accounting, the deferred income tax is considered to be one of the instruments for applying acknowledged accounting principles; namely, the precautionary principle, the accrual principle, the asset preservation principle (continuation of the accounting entity's existence in the near future) and other accounting principles (for more see Jílek and Svobodová, 2006):

- Accrual principle - the accounting entity is required to record costs and revenues in the period they are related to. Deferred tax liabilities (deferred tax receivables) are recorded on cost accounts, it is necessary to record them and their influence on the profit/ loss in the period during which temporary differences occur.

- Precautionary principle - the accounting entity should also account for potential payables and costs, and must not overvalue recorded profits. A deferred tax liability, debited to costs and lowering the profit accounted for, is a liability that the accounting entity will have to settle in future periods. Conversely, a deferred tax receivable represents a receivable that may or may not be received in the future.
This is why the precautionary principle should be observed when accounting for deferred tax receivables.

- Asset preservation - if, in the period during which a deferred tax liability occurred and remained unaccounted for, the accounting entity divided the entire available income, its assets would be influenced. Therefore, the entity would put its future existence in jeopardy.

In most countries, the income tax base is calculated from the profit/loss shown in accounting records. However, there are significant differences in the extent and character of adjustments used in tax base transformations. There are two extremes: Germany, where the majority of companies do not make any adjustments, and the United States, where a good number of adjustments are made. Other countries are between these two extremes. It means that adjustments are made but there are fewer of them. Based on this fact, Nobes (2004) has classified the relation between accounting and tax reporting, and established five groups of relations. ${ }^{1}$

In the Czech Republic, the current functional model of accounting (for entrepreneurs, for banks and other financial institutions, and for insurance companies) which is derived from Act No. 563/91 Coll., on accounting, as amended - does not represent tax accounting. It means that at the end of the year, when the accounting books have been closed, the accounting entity determines its pre-tax profit or loss which (for the purpose of taxation) has to go through a nonaccounting adjustment by cost entries that are, according to the Income Tax Act, acknowledged as costs but with a different value or that are not eligible costs at all, or by items that lower the economic result (tax losses from previous years). This leads to differences between the recorded profit/loss and the income tax base concerning the given period. The differences may be permanent or temporary.

Permanent differences occur when costs or revenues are, neither in the current nor in other tax periods, part of the tax base and they do not cause the deferred tax.

Temporary differences are differences between the accounting profit/loss and the income tax base

1 Types of relation between tax and accounting records:

Category I - disparity - different rules for tax and accounting purposes

Category II - identity - certain relevant rules are identical for both tax and accounting purposes

Category III - accounting prevalence - the accounting rule holds good for both tax and accounting purposes because the relevant tax rule is missing

Category IV - tax prevalence - the tax rule holds good for both tax and accounting purposes because the relevant accounting rule is missing

Category $\mathrm{V}$ - tax dominance - the tax rule holds good for both tax and accounting purposes because it dominates the accounting rule. 
originating from the fact that some book entries are part of costs or revenues in a different accounting period and in another period they were used for the calculation of the income tax, or from the difference between the net book value and the asset/liability tax base. For these purposes, the asset tax base is understood as asset value that can be used for tax purposes in the future. According to Jílek and Svobodová (2006), it is represented by an amount the accounting entity will be able to deduct from the taxable profit, which will result from deducting the book value of the asset. As profits from assets we can understand income from assets that either influences or doesn't influence the tax base. If profits do not influence the tax base then the asset tax base equals its book value. A liability tax base is an amount that can be matched with the taxable liability. It is represented by a value that the accounting entity will be able to deduct for taxation purposes in the future.

Therefore, the deferred tax comes into existence as a result of temporary differences between the net book value of assets and liabilities shown in the balance sheet, that is, their gross value minus corrections (accumulated depreciation, adjusting items) and their tax base shown for the purpose of income tax base calculation. It can also result from time differences originating from the fact that costs and revenues are eligible (for accounting- and tax purposes) in different periods.

Insurance companies may account for the deferred income tax as of the beginning of the 1990s; at that time it was compulsory for only a limited number of accounting entities, which made a consolidated financial statement (companies in a group). Also, the methodology for the calculation of and accounting for the deferred income tax was different.

Under the current legislation governing insurance companies' accounting, the procedure of calculating and accounting for the deferred income tax is based on the liability method and the balance approach, as mentioned by Čejková and Valouch (2005), that is, just like in regular companies' accounting. The core of the liability method lies in that the deferred tax related to the recorded profit/loss will be applied in a later period; this is why the calculation of the tax is based on the income tax rate effective in the period in which the tax is applied (tax receivable, tax liability). It is a long-term receivable/liability, as the time incongruity is adjusted over a number of accounting (tax) periods. The impact of the deferred tax on the profit and loss account is considered to be of a lesser importance, the actual amount being dependent on the deferred tax amount recorded in the balance sheet. The balance approach means showing the temporary differences between the net book value and the tax base of all balance sheet entries.
The temporary differences between the book value and the tax base can be classified by two points of view: whether the differences cause deferred tax receivables or liabilities, or asset-related differences and liability-related differences.

In the following text, our point of departure will be the latter classification, i.e. asset- or liability-related differences.

As far as assets are concerned, an important temporary difference is the one resulting from a different procedure of applying book depreciation (in accordance with the accounting entity's depreciation plan) and tax write-offs as required by the Income Tax Act. For accounting purposes, the accounting entity (insurance company) has to follow one of the main accounting principles - the "true and fair view" principle, and it is fully in its competence to decide about the accounting lifetime and the methodology, because the aim of book depreciation is to show permanent decrease in the value of fixed assets and its transfer onto the cost account. On the other hand, for tax purposes, the methodology and time of depreciation are prescribed in the Act on income taxes by the state.

Temporary differences in the insurance company's assets can result from revaluation towards their real value, as the asset tax base is not influenced at the moment of revaluation.

If the fixed assets' market value is lower than the net book value of these assets, accounting entities make adjustments to fixed assets. The making of adjusting items results from the application of the precautionary principle and is solely an accounting matter; the value of the adjusting item does not influence the asset tax base.

For assets that are registered in the insurance company's accounting books as financial placement of technical provisions, directive No. 502/2002 Coll., as amended by directive No. 474/2003 Coll. (in force as of $1 / 1 / 2004$ ), has cancelled the possibility to depreciate financial placements that take the form of a building or a construction. Also, such financial placements of the insurance company's technical provisions cannot be adjusted through adjusting items, because the particular financial placement is revaluated to its real value. In relation to tax, financial placements in the form of buildings or constructions are depreciated in accordance with the Income Tax Act. The difference between what results from revaluating a financial placement to its real value and its tax base, is the basis for the calculation of the deferred income tax; however, the tax - just like the financial placement revaluation itself - is only accounted for in the balance sheet as a change in the equity capital, and at the moment of making the financial placement the deferred tax is accounted for in the balance sheet 
through a book entry with a value reverse to the one recorded when the tax occurred.

Trade receivables represent, in insurance companies' accounting, a rather important item; nevertheless, temporary differences can occur there as well. Unpaid trade receivables, where it is not likely for the accounting entity to receive the full amount, can be adjusted through adjusting items in accordance with the precautionary principle. Supposing that in the future the adjusting item will become an adjustment to receivables made according to the law, this difference can be considered temporary.

With receivables that are claims to a contractual interest on overdue payment and contractual sanctions, the temporary difference is the outcome of different rules for determining, for tax purposes, the moment when costs or expenses occurred. The income tax base is only lowered when they have been settled.

The most important group of insurance company liability-related temporary differences are differences caused by creating provisions that are not tax eligible. In accordance with Act No. 593/1992 Coll., on provisions for the determination of the income tax base, as amended by subsequent legislation, insurance companies create provisions the creation of which is an eligible cost. These are provisions an insurance company creates in accordance with Act No. 363/1999 Coll., on the insurance industry and amendments to certain related laws, as amended by Act No. 39/2004 Coll., in the sphere of life- and non-life insurance (Vávrová, Doložílková, Stuchlík; 2004).

Creation of other provisions mentioned (see following text) under paragraphs $h$ ) and $f$ ) is approved by the supervising authority following the insurance company's request. The request includes a proposal for how to create and use this provision. Provision creation beyond the ceiling calculated using the methods stipulated by Act No. 363/1999 Coll., on the insurance industry, as amended by Act No. 39/2004 Coll., is not taken as cost lowering the income tax base. However, actual costs of items for which provisions have been created are tax eligible costs: therefore, in such cases a temporary difference between the net book value of the liability and its tax base comes into existence.

On accounts that belong in accounting group $44-$ "Technical provisions", insurance companies account for technical provisions according to special insurance industry-related legislation (Act No. 363/1999 Coll., on the insurance industry and amendments to certain related laws, as amended by subsequent legislation; and the Ministry of Finance Decree No. 303/2004 Coll., which implements Act No. 363/1999 Coll.). Czech accounting standard for insurance companies no. 207 recommends establishing accounts at least for the individual technical provisions.
From the perspective of accounting, technical provisions represent the valuation of the insurance company's future liabilities arising from its insurance and reinsurance activity. These liabilities will likely or certainly occur; what is uncertain is the amount of the liability or the time of its occurrence.

The amount of technical provisions is determined so that it is, at any time, sufficient enough for the insurance company to fulfil its obligations given by insurance contracts.

When accounting for the creation and use of these provisions, their gross amount as well as the share of reinsurers in the provisions are recorded.

Analytical accounts are kept separate and in a way that allows finding:

a) the share of the reinsurer(s) in the creation and use of the provisions

b) transfers or transitions of provisions in connection with additions or losses in the portfolio of insurance policies

c) change in the state of the given provision.

The change in the state of the provision is calculated as a difference between the final and the initial balance of the given provision. Change in the state of the provision (the difference) is calculated as a gross amount, from which the reinsurers' share is calculated.

Technical provisions are debited to costs; however, from the tax perspective the entire amount of a provision does not have to be acknowledged as an eligible cost. According to Act No. 593/1992 Coll., eligible (in relation to the income tax) is the creation of provisions that are costs (expenses) associated with obtaining, securing and maintaining income:

- for non-life insurance, an amount that must not exceed the amount of liabilities calculated using methods that are stipulated by special legislation (Act No. 363/1999 Coll., on the insurance industry)

- for life insurance, an amount that must not exceed the amount of liabilities calculated using methods stipulated by special legislation (Act No. 363/1999 Coll.) and that arises from life insurances payable according to concluded insurance contracts.

In accordance with their business objective, insurance companies create the following provisions according to Act No. 363/1999 Coll., on the insurance industry:

1. Non-life insurance provisions

a) unearned premium provision

b) provision for insurance payments

c) provision for bonuses and rebates

d) equalisation provision

e) non-life insurance premium provision

f) other provisions. 
2. Life insurance provisions

a) unearned premium provision

b) life insurance premium provision

c) provision for insurance payments

d) provision for bonuses and rebates

e) life insurance provision, if the investment risk is borne by the insurant

f) provision for liabilities arising from the applied technical interest rate

g) non-life insurance premium provision

h) other provisions.

Each technical provision is accounted for separately from other liabilities of the insurance company. The insurance company is required to submit a report on the creation and amount of technical provisions as well as on the structure of the financial placement of assets that are based on technical provisions. The report is submitted to the supervisory authority biannually, on 30 June and 31 December in the current year. The deadline is up to 60 days after the respective date.

In the following text we will use the methodology based on a sample chart of accounts by Čejková and Valouch (2005) according to Decree No. 502/2002 Coll.

Unearned premium provision - is debited to costs (for both life- and non-life insurance), at an amount that equals the premium relating to future accounting periods. It is, therefore, a form of time differentiation of the premium. This provision relates to the prescribed gross premium (technical revenue accounts for non-life or life insurance) and to the share of the reinsurers (again, technical revenue accounts for non-life or life insurance). The standard method used for the creation of this provision is the "pro rata temporis" method, or alternatively, the "24th method". It is possible to use other methods that make it possible to obtain results corresponding to results obtained using the standard methods. Analytical records are kept separate for life- and non-life insurance. Information on the method used to create this provision must be mentioned in the appendix to the financial statement. The creation of unearned premium provision is credited to account 441- Unearned premium provision, and debited to two cost accounts 505 or 523 - Creation of unearned premium provision (the first account is included in the Non-life insurance technical account, the other is included in the Life insurance technical account), depending on whether it is created for life- or non-life insurance. The use of the unearned premium provision is then debited to account $441-$
Unearned premium provision (the selection of a particular account is governed by the same criterion as the creation of provisions).

Life insurance premium provision - the life insurance premium provision is calculated based on individual life insurance contracts, and is intended to cover future liabilities arising from life insurances. For calculation purposes, the statistical data and the interest rate are the same as for the premium rate calculation. The life insurance premium provision represents an amount of insurance company liabilities calculated using actuarial methods, including the profit shares already accounted for (shares in premium surplus) and cost provisions relating to insurance administration, after the value of the future premium has been deducted. If the resulting values are negative, the provision is not created. The creation of this provision is credited to account 442 - Life insurance premium provision, and debited to cost account 527 - Creation of life insurance premium provision. The use of this provision is debited to account 442 - Life insurance premium provision, and credited to revenue account 627 - Use of life insurance premium provision (in this case, both cost and revenue accounts are included in the Life insurance technical account).

Provision for insurance payments - is intended for:

a) insurance payments arising from insured accidents reported before the end of the accounting period but not settled in the current accounting period (RBNS provision ${ }^{2}$ )

b) insurance payments arising from insured accidents occurring in the current period but not reported to the insurance company before the end of the accounting period (IBNR provision ${ }^{3}$ ).

The provision for insurance payments also includes the estimated cost of the settlement of the insured accidents. The amount of the provision is a total of costs for insurance payments calculated for individual insured accidents. The provision for insurance payments is lowered by an estimated claimable amount that the insurance company is entitled to in connection with the insurance payments. If the precise amount cannot be determined for a kind of provision, a qualified estimation or mathematical-statistical methods are to be used. This provision is created for both non-life and life insurance. The creation of this provision is credited to account 443 - Provision for insurance payments, and debited to cost accounts 503 or 525 - Creation of provision for insurance payments. The use of this provision is debited to account 443 - Provision for insurance payments, and credited

2 RBNS stands for „reported but not settled“

3 IBNR stands for ,incurred but not reported“ 
to revenue accounts 603 or 625 - Use of provision for insurance payments.

Provision for bonuses and rebates - this type of provision is created for bonuses and rebates which are provided to the insured according to the terms and conditions of insurance. As a matter of fact, it is the balancing of incomes from the premium lowered by the provided bonuses and rebates. These provisions are accounted for in account 444 - Provision for bonuses and rebates. Amounts accountable for in a current accounting period are recorded here by reason of:

- premium bonuses and rebates

- profit shares (premium surplus, above all)

- premium bonuses refunds

- other business-related amounts intended for the benefit of the insured or other parties contractually entitled to insurance payment.

The given amounts are accounted for in account 444 - Provision for bonuses and rebates, solely on the condition that they have not been accounted for in another provision account. If a substantial amount of profit shares is concerned, it must be recorded in the appendix to the financial statement.

The creation of the provision for bonuses and rebates is credited to account 444 - Provision for bonuses and rebates, and debited to two cost accounts 514 or 536 - Premium bonuses and rebates (again, according to the type of insurance).

Equalisation provision - is created for the class of Credit insurance and for the classes of non-life insurances where fluctuations in loss ratio occur frequently due to facts the insurance company cannot influence. The equalisation provision is meant to equalise increased costs for insurance payments arising due to these fluctuations. This provision is accounted for in account 445 - Equalisation provision. The creation of this provision is credited to this account, and debited to cost account 509 - Creation of equalisation provision. The use of the provision is then debited to account 445 - Equalisation provision, and credited to revenue account 609 - Use of equalisation provision (in this case, both cost and revenue accounts are included in the Non-life insurance technical account).

Life insurance provision, if the investment risk is borne by the insurant - this provision is created for life insurance if the investment risk arising from this insurance is borne by the insurant. This provision is accounted for in account 446 - Life insurance provision, if the investment risk is borne by the insurant. This provision is related to accounting in accounting group referred to as Financial placement in life insurance, if the investment risk is borne by the insurant (within account class 1). The provision is intended to cover the insurance company's liabilities towards the insured, provided the risk of premium revenue variability is only borne by the insurant. The amount of the provision is calculated as a total of revenues from placed premiums from individual contracts according to the terms and conditions of insurance.

Non-life insurance premium provision - Non-life insurance premium provision is created for the insurance classes where the premium is calculated based on the joining age, i.e. the difference between the calendar year of insurance contract conclusion and the calendar year of birth of the insured, and the sex of the insured, or only based on the joining age of the insured.

The non-life insurance premium provision represents the amount of insurance company liabilities calculated by actuarial methods including the profit shares already accounted for (shares in premium surplus) or contractual claims to the refund of premium and provisions for the insurance administration costs, after having deducted the value of future premium.

In compliance with a special legal regulation, the non-life insurance premium provision is accounted for in account 447 - Non-life insurance premium provision. Information on this provision must be provided in the appendix to the financial statement.

Provision for liabilities arising from the applied technical interest rate - if the current or expected revenue from the insurance company's assets is not sufficient to settle liabilities arising from the technical interest rate applied, the insurance company is obliged to create a technical provision intended for settling these liabilities. The insurance company is obliged to submit the technical provision calculation method to the supervising authority for approval as soon as it finds about the insufficiency of the asset revenue.

Other provisions - accounted for in account 449 - Other provisions. These are liabilities and other amounts debited to the insurance company (e.g. a provision for imminent insurance loss) not included in any previous technical provisions in accounting group 44 - Technical provisions. In this account insurers account for the creation and use of the technical provision to guarantee liabilities of the Czech Insurers' Bureau pursuant to a special legal regulation (Article 18 Section 6 of Act No. 168/1999 Coll.). The state of this provision and the report on the use of the provision is included in the appendix to the financial statement. Analytical records are kept separate for individual technical provisions. Their state is given in the appendix. The creation of these provisions is credited to account 449 - Other provisions, and debited to cost accounts 507 or $529-$ Creation of other provisions. The use of the provisions is then debited to account 449 - Other provisions, and credited to revenue accounts 607 or 629 - Use of other provisions. 
If reinsurance is related to a particular insurance (insurance contract), the respective reinsurer's share must be considered and also accounted for while creating the technical provisions. However, the equalisation provision is not included in the reinsurance.

In accounting group 45 - Provisions for other risks and losses, provisions arising from the Act on Provisions and the Accounting Act are accounted for, as well as other provisions relating to the application of the precautionary principle, in particular. Among provisions accounted for in this accounting group there is a provision for pensions and similar liabilities, a provision for the income tax, a provision for risks and losses, and a provision for restructuring. In this accounting group, it is also possible to account for provisions defined by special legal regulations, such as Act No. 593/1992 Coll., on provisions for the determination of the income tax base, as amended by subsequent legislation. Analytical records are kept separately for the individual types of provisions. Their state is given in the appendix to the annual financial statement.

The above mentioned provisions are intended to cover risks, losses and other liabilities that are clearly defined and that will likely or certainly occur at the time of valuation but the amount of the liability or the time of its occurrence is uncertain. When auditing the provisions, their amount and tenability are considered. The provisions cannot be used for costs having no relation to the original liability the provision was created for. Also, provisions cannot be used for costs covered from the equity capital in compliance with special legislation. Furthermore, the provisions cannot be used for temporary or permanent decrease in the value of assets (for more information see Čejková and Valouch, 2005).

Following reason which could cause the deferred tax is liability arising from the unpaid premium for social security and health insurance. It represents an item in which, in insurance companies' accounting, temporary differences can occur rather rarely. In the part of the liability that has arisen from the insurance covered by an employer, the temporary difference results from costs being found non-eligible for a premium that has not been paid before the end of the month following the accounting period at the latest. It only becomes a tax eligible expense at the time of payment.

In case of premium for social security and health insurance deducted by an employer the income tax base is also increased by the unpaid amount, and a temporary difference occurs.

Real estate taxes, real estate-transfer taxes and other taxes that are considered as costs lowering the income tax base are debited to costs; however, they only be- come costs lowering the income tax base at the moment of their payment. Thus, even in this case temporary differences occur.

In the sphere of liabilities arising from contractual interests on overdue payment and contractual sanctions, a temporary difference between the book value and the tax base comes into existence due to the fact that they become tax eligible costs at the moment of their payment.

Another reason why temporary differences occur is the possibility of deducting tax losses from previous years from the income tax base. Therefore, the accounting entity can lower the tax base by amounts that are not recorded in accounting books. In this case, the accounting entity must consider carefully whether, in the future, it will achieve such income tax bases making it possible to apply the tax loss in full. If not, the deferred tax receivable should not be considered, or it should not be considered in full extent.

For assets (A), temporary differences (DR) can be expressed as a difference between the assets book value (ÚH) and their tax base (DZ), according to Bohušová and Svoboda (2005) methodology:

$$
\mathrm{DR}(\mathrm{A})=\mathrm{U}^{\prime} \mathrm{H}-\mathrm{DZ}
$$

For liabilities (P) it is vice versa, i.e. temporary differences (DR) can be expressed as a difference between the liabilities tax base (DZ) and their book value (ÚH):

$$
\mathrm{DR}(\mathrm{P})=\mathrm{DZ}-\mathrm{U} H
$$

If the value of temporary differences is negative, it is a future deferred tax receivable (ODP); if the resulting value of temporary differences is positive, it is a future deferred tax liability (ODZ).

The value of temporary differences is multiplied by the income tax rate expected to be valid at the period the respective difference will be applied, provided that the tax rate for the period is known:

$$
\mathrm{ODP}(\mathrm{ODZ})=\mathrm{DR} * \text { income tax rate }
$$

The total sum of multiplied differences represents the deferred tax liability, i.e. the amount of income tax to be covered in future periods, or a deferred tax receivable, i.e. the amount of income tax to be claimed in future periods. The accounting entity (the insurance company) always accounts for a deferred tax liability. The deferred tax receivable is accounted for by the accounting entity in compliance with the precautionary principle, if it is highly probable that the tax base for which the differences can be used will be achieved. 


\section{FINDINGS AND DISCUSSION}

To account for the income tax in insurance companies' accounting, account 371 - Income tax is used. Advance payments paid during the year are accounted for here. When closing accounting books, an insurance company's liability arising from the tax due for the accounting period is debited here with a corresponding entry in account 571 - Income tax on ordinary income - due, and to account 573 - Income tax on extraordinary income - due, correspondingly with account 371 - Income tax. The insurance company accounts for the deferred income tax in account 572 - Income tax on ordinary income - deferred, and in account 574 - Income tax on extraordinary income - deferred, with a corresponding entry in account 377 - Deferred tax liability or receivable. The methodology mentioned above is based on a sample chart of accounts (Čejková and Valouch, 2005). In contrast to corporate accounting (see Bohušová and Svoboda, 2005), this account is included in account class 3 Receivables, liabilities and temporary accounts, used particularly to account for current liabilities (though this is a long-term liability/receivable).

When first accounting for the deferred tax, the differences relating to previous accounting periods are accounted for in the equity capital; the amount related to the current period is recorded in the profit and loss account, as in the following accounting periods.

Insurance companies are obliged to describe the method of calculating the respective amount in the appendix to the financial statement. They are obliged to do so even if the deferred tax is represented by a deferred tax receivable, and it is not expected to achieve such profit/loss in future periods allowing to use the deferred tax receivable while the deferred tax receivable is not accounted for. Subsequently, the appendix to the financial statement can be used for the analysis of reasons leading to the occurrence of temporary differences.

In compliance with IAS 12 - Income Taxes, accounting for the deferred tax aims to partially remove the discrepancy between the effective profit tax rate and the real profit tax rate resulting from the difference between book and tax values. For this purpose, a rate considered to be effective is a rate calculated as a quotient of the profit tax and the amount of profit/ loss before taxation (Jílek and Svobodová, 2006).

The analysis has been performed on a set of empirical data gathered from five insurance companies in which the financial statement is prepared according to the Czech Accounting Standards for insurance companies, and which are obliged to record deferred income tax by law. The accounting periods examined are the years 2003 and 2004 based on published annual reports of the insurance companies (Česká pojišt'ovna a.s., ČSOB Pojišt'ovna, a.s., člen holdingu ČSOB, Generali Pojištovna a.s., Kooperativa, pojišt'ovna, a.s., UNIQA pojišt'ovna, a.s.). The data for the analysis has been gathered from the insurance companies' annual reports published on the Internet. Attached to the annual report is a financial statement, including its appendix. It contains information on the methodology used to calculate the deferred income tax, including all reasons leading to the occurrence of temporary differences.

During the analysis the structure of items causing the deferred tax in insurance companies has been examined. The items have been examined in absolute values regardless of the influence they have on the nature of the deferred tax. When processing information concerning the structure of the deferred income tax, statistical methods described in Seger, Hindls, Hronová (1998) have been used. The aim of the partial analysis is to identify the role of individual items that cause the deferred tax in insurance companies.

The main objective of the paper was to evaluate:

1. the influence of accounting for the deferred income tax on the amount of available income accounted for in the set of commercial insurance companies concerned.

2. the influence of recording the deferred income tax in insurance companies on the amount of ratio indicators describing the economic performance.

3. the influence of accounting on the amount of effective income tax rate and the relation to the nominal rate.

The methodology used to evaluate economic performance of a respective insurance company is based on methodologies described in Sůvová (1999), and the methodology used to evaluate the influence of the deferred income tax on the effective income tax rate is based on Svoboda and Bohušová (2005).

The analysis of the structure of the deferred income tax has been performed in a set of five insurance companies based on data from the appendix to the financial statement. The structure is shown in Tab. I, Tab. II: 
I: The structure of the deferred income tax in a set of insurance companies in 2003 (in \%)

\begin{tabular}{|l|c|c|c|c|c|}
\hline Item & 01 & 02 & 03 & 04 & 05 \\
\hline Adjustments to assets & & & & & 61.69 \\
\hline Provisions & & 66.68 & & & \\
\hline Net book value of fixed tangible assets & 14.70 & & 24.32 & 25.12 & \\
\hline Adjustments to receivables & & 33.32 & 23.59 & 3.21 & \\
\hline Other temporary differences & & & 1.79 & & \\
\hline Tax losses from previous years & & & & & \\
\hline Estimated entries for social security/health insurance & 6.74 & & & & \\
\hline Revaluation to real value & 78.56 & & 50.30 & 71.67 & 38.31 \\
\hline
\end{tabular}

Source: Insurance companies' annual reports

II: The structure of the deferred income tax in a set of insurance companies in 2004 (in \%)

\begin{tabular}{|l|c|c|c|c|c|}
\hline Item & 01 & 02 & 03 & 04 & 05 \\
\hline Adjustments to assets & & & & & 18.80 \\
\hline Provisions & & 89.11 & & 3.24 & \\
\hline Net book value of fixed tangible assets & 19.71 & & 15.20 & 42.44 & 6.06 \\
\hline Adjustments to receivables & & 10.89 & 14.93 & 1.57 & \\
\hline Other temporary differences & & & 0.71 & & \\
\hline Tax losses from previous years & & & & & \\
\hline Estimated entries for social security/health insurance & 5.01 & & & & \\
\hline Revaluation to real value & 75.28 & & 69.17 & 52.75 & 75.14 \\
\hline
\end{tabular}

Source: Insurance companies' annual reports

Tables I and II imply that the structure of the deferred income tax is rather different in the individual insurance companies. In majority of the entities, the crucial part in the structure in both the periods concerned is represented by the "Revaluation to real value" item. However, the deferred tax arising from the item mentioned is accounted for only in the balance sheet, i.e. it has no influence on the amount of the deferred income tax accounted for in profit and loss accounts. Thus, the amount of available income from the item mentioned is not influenced.

The "Provisions" item, which an insurance company creates to cover risks relating to its sphere of business, also plays an important part in the structure of deferred income tax in insurance companies' accounting. The creation of provisions not exceeding the amount stipulated by Act No. 593/1992 Coll., on provisions for the determination of the income tax base, as amended by subsequent legislation, is a cost lowering the income tax base. Certain insurance companies $(02,04)$ create (in compliance with the internal regulations of the insurance company) higher provisions, which leads to the occurrence of temporary differences between the book value and their tax base. The share in the entities mentioned amounts up to $89 \%$.

In the selection of insurance companies concerned, the "Net book value of the fixed assets" and "Adjustments to assets" items are rather important items in the structure of deferred income tax. They represent a share ranging from $0 \%$ (in $01,02,04$ ) through to $62 \%$.

The "Adjustments to receivables" item is also a rather important item representing the share ranging from $0 \%$ through to $33.32 \%$. The other items represent not very important amounts in the structure of temporary differences that cause the occurrence of deferred tax in insurance companies accounting.

The average structure of temporary differences that cause the occurrence of deferred tax in a set of insurance companies in the periods concerned is shown in the Fig. 1, 2: 


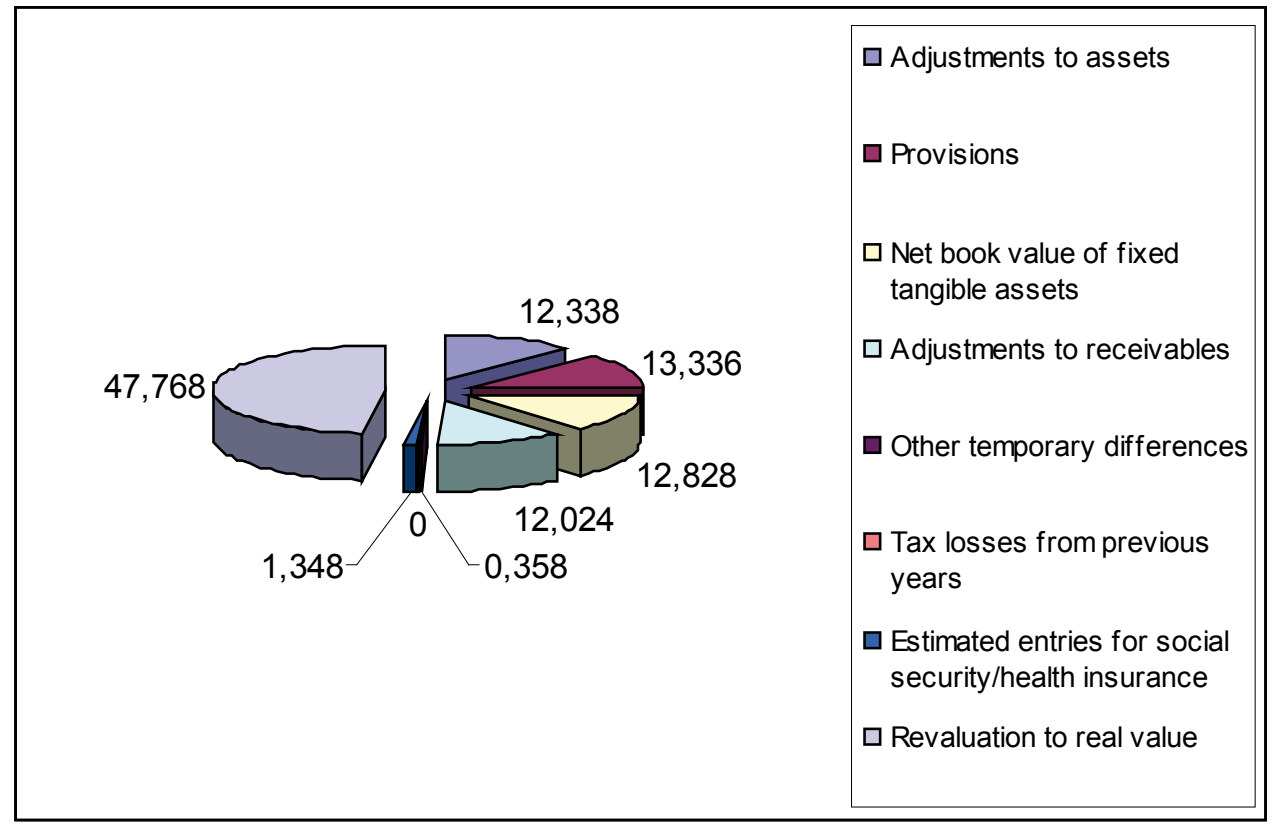

1: Average structure of the deferred income tax in 2003

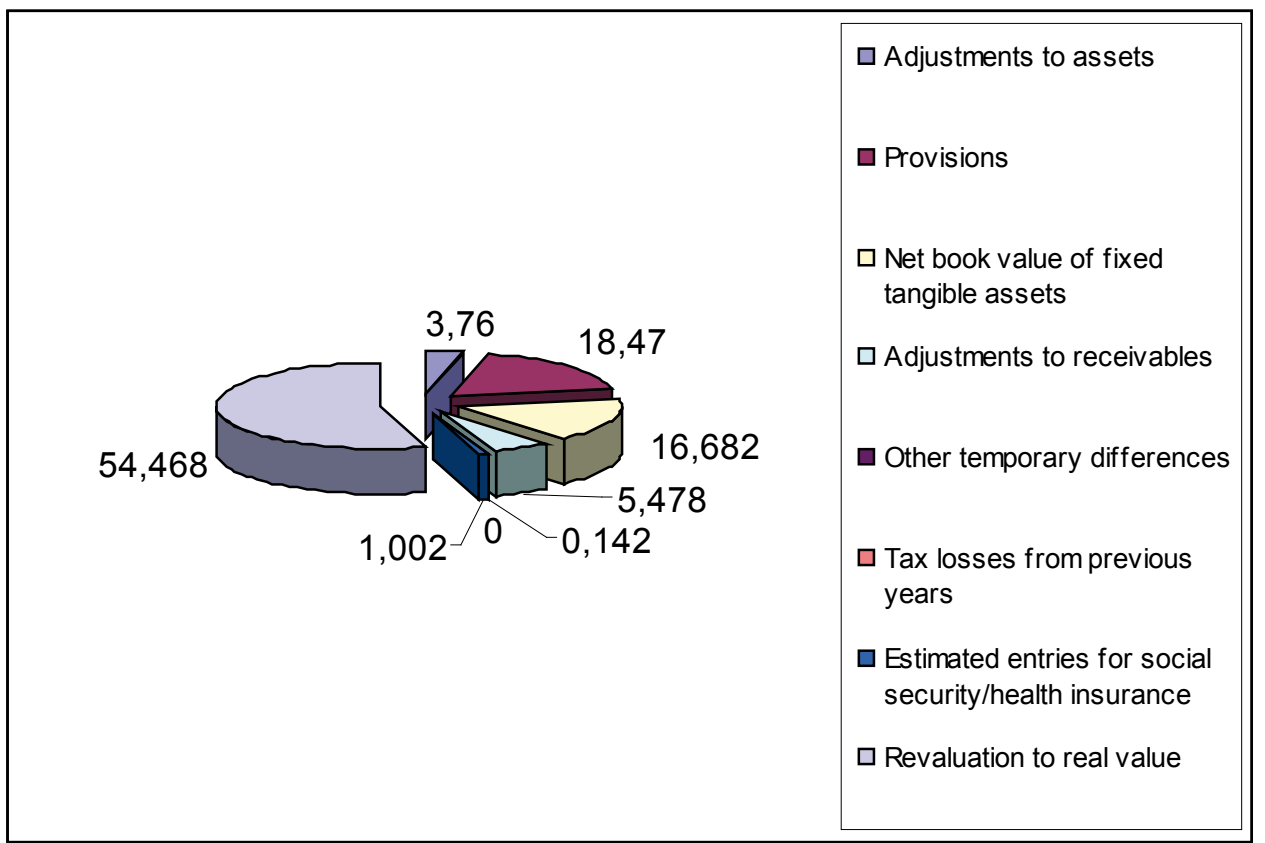

2: Average structure of the deferred income tax in 2004

The values of indicators and ratio indicators for the evaluation of the influence of recording the defer- red income tax in insurance companies are recorded and calculated in following tables, Tab. III-VI: 
III: Absolute values of indicators of the insurance companies concerned-deferred tax and profit/loss in 2003

\begin{tabular}{|l|r|r|r|r|c|}
\hline Item (CZK thousands)/accounting entity & \multicolumn{1}{|c|}{01} & \multicolumn{1}{c|}{02} & \multicolumn{1}{c|}{03} & \multicolumn{1}{c|}{04} & 05 \\
\hline Deferred tax - cost & 42,295 & 24,785 & $-644,396$ & $-6,408$ & $*-5,172$ \\
\hline Deferred tax receivable (-)/ liability (+) & 42,965 & $-5,985$ & 628,991 & 93,848 & $-19,425$ \\
\hline Profit/loss before taxation & $-31,531$ & 88,552 & $4,542,248$ & 683,716 & 124,970 \\
\hline Available income & $-73,826$ & 45,575 & $3,161,060$ & 448,196 & 75,680 \\
\hline
\end{tabular}

Source: Insurance companies' annual reports

IV: Absolute values of indicators of the insurance companies concerned-deferred tax and profit/loss in 2004

\begin{tabular}{|l|r|r|r|r|r|}
\hline Item (CZK thousands)/accounting entity & \multicolumn{1}{|c|}{01} & \multicolumn{1}{c|}{02} & \multicolumn{1}{c|}{03} & \multicolumn{1}{c|}{04} & 05 \\
\hline Deferred tax - cost & 2,050 & 850 & 267,213 & $-103,458$ & $-5,999$ \\
\hline Deferred tax receivable (-)/ liability (+) & 45,015 & $-2,964$ & $1,752,298$ & 75,694 & 36,912 \\
\hline Profit/loss before taxation & 578,328 & 298,240 & $5,536,113$ & 765,247 & 722,594 \\
\hline Available income & 500,399 & 213,817 & $4,200,767$ & 490,288 & 527,318 \\
\hline
\end{tabular}

Source: Insurance companies' annual reports

V: Selected ratio indicators in 2003

\begin{tabular}{|l|c|c|c|c|c|}
\hline Indicator/accounting entity & 01 & 02 & 03 & 04 & 05 \\
\hline The proportion of the deferred tax and the total income tax & 1.00 & 0.58 & 0.46 & 0.03 & $* 4$ \\
\hline The proportion of the deferred tax and available income & -0.57 & 0.54 & 0.20 & 0.10 & $*$ \\
\hline Profitability of equity capital (without deferred tax) & $* 5$ & 0.11 & 0.25 & 0.16 & 0.07 \\
\hline Profitability of equity capital (with deferred tax) & $*$ & 0.10 & 0.20 & 0.17 & 0.08 \\
\hline Effective tax rate (without deferred tax) & $*$ & 0.20 & 0.16 & 0.35 & 0.40 \\
\hline Effective tax rate (with deferred tax) & $*$ & 0.27 & 0.30 & 0.34 & 0.33 \\
\hline
\end{tabular}

Own calculation based on annual reports data

VI: Selected ratio indicators in 2004

\begin{tabular}{|l|c|c|c|c|c|}
\hline Indicator/accounting entity & 01 & 02 & 03 & 04 & 05 \\
\hline The proportion of the deferred tax and the total income tax & 0.04 & 0.01 & 0.21 & $*$ & $*$ \\
\hline The proportion of the deferred tax and available income & 0.01 & 0.01 & 0.06 & $*$ & $*$ \\
\hline Profitability of equity capital (without deferred tax) & 0.25 & 0.33 & 0.24 & 0.07 & 0.54 \\
\hline Profitability of equity capital (with deferred tax) & 0.25 & 0.33 & 0.23 & 0.09 & 0.55 \\
\hline Effective tax rate (without deferred tax) & 0.12 & 0.28 & 0.19 & 0.55 & 0.27 \\
\hline Effective tax rate (with deferred tax) & 0.13 & 0.28 & 0.24 & 0.40 & 0.29 \\
\hline
\end{tabular}

Own calculation based on annual reports data

Tables III and IV imply that due to recording the deferred income tax in the profit/loss statement (in profit and loss accounts - depending on the nature of the deferred income tax, it can be recorded as a cost or as an item lowering costs) the profit/loss is accounted for in compliance with all principles applied in the contemporary function model of accounting for insurance companies (accrual principle, precautionary princi-

4 the data cannot be expressed numerically, the deferred tax is negative

5 the data cannot be expressed numerically, as the insurance company recorded loss in the period monitored 
ple). If the deferred income tax is debited to costs, the profit/loss accounted for is lowered; or, vice versa, the available income is increased. In insurance companies 01,02 the available income was lowered in 2003; in insurance companies 03, 04 and 05 the available income was increased. In 2004 the profit/loss in 01, 02 and 03 was lowered, and in 04 and 05 it was increased due to accounting for the deferred income tax.

Accounting for the deferred income tax as costs leads to lowering the available income accounted for; it prevents the accounting entity (the insurance company) from allocating a greater amount of profit/loss than was really created in the respective period. The asset preservation principle is observed.

Accounting for the deferred income tax also influences the values of ratio indicators describing the economic performance of a company, as shown in Bohušová and Svoboda (2005). Provided that the numerator of the equity capital profitability indicators is the available income, the deferred income tax is influenced depending on its nature (a cost or an item lowering costs). If the deferred income tax is debited to costs, the capital profitability is lowered; or, vice versa, the profitability is increased in consequence of deferred tax recording.

The accounting for the deferred income tax in the insurance companies concerned has a minor influence on the profitability of the equity capital (in tenths of percent).
One of the main objectives of accounting for the deferred tax is to remove the discrepancy between the effective income tax rate $^{6}$ and real rate (nominal) ${ }^{7}$.

Ideally, accounting for the deferred income tax would lead to the same amounts of effective income tax rate and the real income tax rate (Svoboda and Bohušová, 2005). This situation, however, can not come into existence due to the current regulations governing taxes and accounting in the Czech Republic, as the difference between the profit/loss accounted for and the income tax base is not only created by the temporary differences, but also by long-term differences.

Tab. V-VI imply that accounting for the deferred income tax in the insurance companies concerned has rather significant influence on the amount of effective income tax rate - the rate approximated the nominal rate in all the entities. In 2003, when the nominal income tax rate of legal entities was $31 \%$, the insurance company 01 accounted for a loss as the tax base; thus, the deferred income tax had no influence on the amount of the effective income tax rate. In insurance company 02 the effective rate increased by $7 \%$ (from $20 \%$ to $27 \%$ ); in 03 by $14 \%$ (from $16 \%$ to $30 \%$ ); in 04 the rate decreased by $1 \%$ (from $35 \%$ to $34 \%$ ) and in 05 by $7 \%$ (from $40 \%$ to $33 \%$ ). In 2004, when the nominal income tax rate was $28 \%$, the effective rate also approximated the nominal rate in all the entities.

\section{SOUHRN}

\section{Struktura odložené daně z př́ijmů a její vliv na ukazatele charakterizující ekonomickou} výkonnost komerčních pojišt'oven

Stěžejním záměrem této práce je prezentace poznatků získaných při analýze titulů, které vedou ke vzniku odložené daně z př́ijmů v komerčních pojišt'ovnách na pojistném trhu v České republice. Hodnocení je cíleno v souladu s koncepcí předkládaného prŕíspěvku na analýzu struktury odložené daně v souboru vybraných pojistitelů sdružených v České asociaci pojišt’oven. Je zkoumán, dokumentován a vyhodnocen vliv zachycení odložené daně z př́ijmů ve vztahu k vykázanému disponibilnímu výsledku hospodaření a ve vztahu k výši efektivní sazby daně z př́ijmů v komerční pojišt'ovně. Tato analýza se vztahuje k hodnocení současného stupně transformace a aproximace českého pojišt'ovnictví v procesu harmonizace s evropským pojišt'ovnictvím.

Zaúčtovat jen splatnou daň z př́ijmů není dostatečné pro podání pravdivého obrazu o finanční situaci účetní jednotky, kterou je komerční pojišt'ovna. Existuje rozdíl mezi vykázaným účetním výsledkem hospodaření a daňovým základem v důsledku cílů fiskální politiky státu. Nástrojem, s jehož pomocí je možné vykázat účetní výsledek hospodaření po zdanění v podobě, která odpovídá ekonomické realitě a ne pouze daňovým předpisům, je odložená daň. Pro stanovení výše odložené daně je použíán rozvahový př́istup, závazková metoda vycházející z dočasných rozdílů mezi daňovou základnou aktiva nebo závazku a jeho

6 Effective income tax rate can be expressed as a quotient of the income tax and the amount of profit/loss before taxation.

7 Rate in accordance with the Income Tax Act. 
účetní hodnotou vykázanou v rozvaze. Dočasné rozdíly mohou vést ke stanovení odloženého daňového závazku nebo odložené daňové pohledávky. Účetní jednotka by měla odloženou daňovou pohledávku a závazek vykázat v rozvaze odděleně nejen od ostatních pohledávek a závazků, ale i splatných daňových pohledávek a závazků, protože se jedná o pohledávku či závazek dlouhodobého charakteru (nebot' k vyrovnání účetní hodnoty a daňové základy dochází v průběhu několika období).

O odložené dani účtují a vykazují ji účetní jednotky, které tvoří konsolidační celek, a účetní jednotky, které sestavují účetní závěrku v plném rozsahu. Účetní jednotka účtuje o odloženém závazku vždy a o odložené daňové pohledávce s ohledem na zásadu opatrnosti.

Analýza byla provedena na souboru empirických dat pěti pojišt'oven, které sestavují účetní závěrku podle Českých účetních standardů pro pojišt’ovny a ze zákona jim vyplývá povinnost zachycovat odloženou dan̆ z př́ijmů. Zkoumanými účetními obdobími byly roky 2003 a 2004 na základě veřejně publikovaných výročních zpráv pojištoven. Data pro analýzu byla čerpána z výročních zpráv pojištoven, které jsou uživatelům k dispozici. Jako součást výroční zprávy figuruje účetní závěrka včetně přílohy, jejíž součástí jsou informace o metodickém postupu pro vyjádření odložené daně z př́ijmů, včetně všech titulů, které vedou ke vzniku dočasných rozdílů.

V průběhu analýzy byla zkoumána struktura titulů, které vedou k účtování o odložené dani v pojišt'ovnách, a to v jejich absolutních hodnotách, bez ohledu na to, jaký vliv budou mít na charakter odložené daně. Cílem této dílčí analýzy bylo zjistit význam jednotlivých titulů, které vedou ke vzniku odložené daně v pojišt’ovnách.

Hlavním cílem př́spěvku bylo zhodnotit:

1. vliv zaúčtování odložené daně z příjmu ve zkoumaném souboru komerčních pojišt’oven na výši vykázaného disponibilního výsledku hospodaření

2. vliv zachycení odložené daně z př́ijmů v pojišt’ovnách na výši poměrových ukazatelů, které charakterizují ekonomickou výkonnost

3. vliv zaúčtování na výši efektivní sazby daně z př́íjmů a vztah k sazbě nominální.

Pojišt'ovny v př́loze k účetní závěrce podrobně vysvětlují tituly vedoucí ke vzniku odložené daně z příjmů. Ve srovnání se souborem podniků, který byl předmětem dřive provedené analýzy (Bohušová, Svoboda; 2005), v souboru pojišt'oven je struktura titulů vedoucích ke vzniku odložené daně poměrně různorodá. Na základě teoretických východisek bylo možno předpokládat, že největší podíl ve struktuře odložené daně z př́ijmů bude připadat na dočasné rozdíly z titulu tvorby a užití technických rezerv, jejichž tvorba, užití a finanční umístění je specifické pro činnost komerčních pojišs'oven. Tato hypotéza se však nepotvrdila. Důvod lze spatřovat v odlišné účetní a daňové politice uplatňované jednotlivými pojišt’ovnami, která je upravena jejich vnitřními směrnicemi.

Zachycení odložené daně z př́jmů má vliv rovněž na hodnoty poměrových ukazatelů charakterizujících ekonomickou výkonnost podniku, jak je rozpracováno v Bohušová, Svoboda (2005). U sledovaných pojišt'oven dochází zachycením odložené daně z př́imů pouze k poměrně nevýznamnému ovlivnění rentability vlastního kapitálu, což je důsledkem skutečnosti, že částka odložené daně zachycená na vrub nákladů je v poměru k dosahovaným hospodářským výsledkům u všech sledovaných komerčních pojištoven nízká.

Zachycení odložené daně z př́ijmů má však poměrně významný vliv na výši efektivní sazby daně z př́ijmů - u všech sledovaných jednotek dochází k přiblížení efektivní sazby daně z příjmů sazbě nominální.

účetnictví, odložená daň z př́ijmu, komerční pojišt’ovna, aktiva, pasiva, ukazatel, životní pojištění, neživotní pojištění

The paper was written as part of research project MSM 6215648904, carried out by the Faculty of Business and Economics, under the name "The Czech Republic in the processes of integration and globalization, and the development of the agriculture and service sector in the new conditions of the integrated European market." 


\section{REFERENCES}

BOHUŠOVÁ, H., SVOBODA, P.: Analýza odložené daně z př́jimů a její vliv na ukazatele charakterizující ekonomickou výkonnost podniku. (An Analysis of the Deferred Income Tax and its Influence on Indicators Describing the Economic Performance of a Company.) Acta Universitatis Agric. et Silvic. Mend. Brun., 2005, LIII, 6. ISSN 1211-8516.

ČEJKOVÁ, V., VALOUCH, P.: Účetnictví pojištoven po vstupu do EU. (Insurance Companies'Accounting after Joining the EU.) Prague: Grada Publishing, 2005. ISBN 80-247-0953-8.

Czech Accounting Standards for accounting entities accounting in compliance with Decree no. $502 / 2002$, as amended by subsequent legislation.

JÍLEK, J., SVOBODOVÁ, J.: Účetnictví bank a finančních institucí. (Accounting of Banks and Financial Institutions.) Prague: Grada Publishing, 2006. ISBN 80-247-1559-7.

NOBES, CH.: A Conceptual Framework for Taxable Income of Business, and How to Apply it under IFRS. Certified Accountants Educational Trust, London, 2003. ISBN 1-85908-379-8.

SEGER, J., HINDLS, R., HRONOVÁ, S.: Statistika v hospodářrství. Praha: ETC Publishing, 1998. ISBN 80-86006-56-5.

SƯVOVÁ, H.: Finanční analýza v ř́zení podniku, v bance a na počitači. Praha: Bankovní institut, 1999. ISBN 80-7265-027-0.

SVOBODA, P., BOHUŠOVÁ, H.: Vliv zachycení odložené daně z př́jmů na efektivní sazbu daně (The Influence of Recording Deferred Income Tax on Effective Tax Rate), Agrární perspektivy XIV Volume I, Prague 2005, ISBN 80-213-1372-2.

VÁVROVÁ, E., DOLOŽÍLKOVÁ, M., STUCHLÍK, R.: Pojištovnictví. (The Insurance Sector.) Brno: MUAF Brno, 2004. ISBN 80-7157-487-2.

Decree No. 502/2002 implementing certain provisions of Act No. 563/1991 Coll., on accounting, as amended by subsequent legislation, for accounting entities that are insurance companies.

Annual reports of accounting entities (commercial insurance companies) [on-line]: http://www.cpoj. cz, http://www.csobpoj.cz, http://www.generali.cz, http://www.koop.cz, http://www.uniqa.cz

Act No. 586/1992 Coll., on income taxes, as amended by subsequent legislation.

Act No. 593/1992 Coll., on provisions for the determination of the income tax base, as amended by subsequent legislation.

Act No. 563/1991 Coll., on accounting, as amended by subsequent legislation.

Act No. 363/1999 Coll., on insurance industry, as amended by Act No. 39/2004 Coll.

Ing. Hana Bohušová, Ph.D., Ústav účetnictví a daní, Ing. Eva Vávrová, Ph.D., Ústav financí, Mendelova zemědělská a lesnická univerzita v Brně, Zemědělská 1, 61300 Brno, Česká republika 